\title{
含 $\mathrm{Fe}_{2} \mathrm{O}_{3}$ 珪酸塩ガラスの赤外線吸収スペクトル
}

\author{
森 永 健 次* 杉之原幸夫** 柳ケ瀬 勉***
}

\begin{abstract}
Kenji Morinaga, Yukio Suginohara and Tsutomu Yanagase : Infrared Absorption Spectra of Silicate Glasses Containing $\mathrm{Fe}_{2} \mathrm{O}_{3}$. Infrared absorption spectra of silicate glasses containing $\mathrm{Fe}_{2} \mathrm{O}_{3}$ have been measured in order to find out the effect of $\mathrm{Fe}_{2} \mathrm{O}_{3}$ on the structure of silicate anion. In binary systems $\mathrm{RO} \cdot \mathrm{Fe}_{2} \mathrm{O}_{3}$ and $\mathrm{R}_{2} \mathrm{O} \cdot \mathrm{Fe}_{2} \mathrm{O}_{3}$, the peak shifts of absorption spectra $\mathrm{Fe}^{3+}-\mathrm{O}^{2-}$ were studied in terms of the oxygen coordination number of $\mathrm{Fe}^{3+}$.

The results indicate that the wave numbers of absorption peaks in $\mathrm{Fe}^{3+}$ (oct.) $\mathrm{O}^{2-}$ and $\mathrm{Fe}^{3+}$ (tetr.) $-\mathrm{O}^{2-}$ were about $580 \mathrm{~cm}^{-1}$ and $625 \sim 660 \mathrm{~cm}^{-1}$, respectively. The oxygen coordination number of $\mathrm{Fe}^{3+}$ varied with the $\left(\mathrm{RO}, \mathrm{R}_{2} \mathrm{O}\right) / \mathrm{Fe}_{2} \mathrm{O}_{3}$ ratio and the basicity of $\mathrm{RO}, \mathrm{R}_{2} \mathrm{O}$. $\mathrm{Fe}^{3+}$ in octahedral sites was predominant for the acidic glasses. It was assumed that the oxygen coordination number of $\mathrm{Fe}^{3+}$ in silicate glasses varied with the basicity of silicate glasses, and $\mathrm{Fe}^{3+}$ (oct.) acted on silicate anion structure as a network modifier.
\end{abstract}

(Received August 27, 1975)

\section{I. 緒 論}

著者らは珪酸塩がラス中の $\mathrm{Fe}^{3+}$ の誉動汇関するメスバ ウアースペクトルの研究から, 理酸塩がラス中での $\mathrm{Fe}_{2} \mathrm{O}_{3}$ は，酸素 4 配位 4 面体 $\left(\mathrm{Fe}^{3 \mathbf{t}}\right.$ (tetr.))之酸素 6 配位 8 面体 $\left(\mathrm{Fe}^{3+}\right.$ (oct.))の双方を形成することができる両性酸化物で 西り, $\mathrm{Fe}^{3+}$ (oct.) $/ \mathrm{Fe}^{3+}$ (tetr.)の比は篮基度,および $\mathrm{Fe}_{2} \mathrm{O}_{3} /$ $\left(\mathrm{R}_{2} \mathrm{O}, \mathrm{RO}\right)$ の值によって変化することを推論した。塩基度 と $\mathrm{Fe}_{2} \mathrm{O}_{3} /\left(\mathrm{R}_{2} \mathrm{O}, \mathrm{RO}\right) の 2$ つの因子考文合せた $\mathrm{O}^{2-} / \mathrm{Fe}^{3+}$ のパラメータ,つまり1值の $\mathrm{Fe}^{3+} に 与$ 与党られる $\mathrm{O}^{2-}$ の数 によって，従来提案された $\mathrm{Fe}^{3+}$ の錯陰イオンの形態を考 察した(1). 本研究では， $\mathrm{Fe}_{2} \mathrm{O}_{3}$ を添加した理酸塩がラスの 赤外線吸収スペクトルを测定し， $\mathrm{Fe}^{3+}$ の酸素配位数の変 化が珪酸陰イオンに及方す影響を主として Si-O $\nu_{3}$ 伸縮报 動数の移行により考察を試みた。尘た若干の $\mathrm{Fe}_{2} \mathrm{O}_{3}$ を主 体とした化合物やガラスの赤外線吸収スペクトルを测定,

酸素配位数による $\mathrm{Fe}^{3+}-\mathrm{O}^{2-}$ の吸収ピークの移行について る考察を加えた。

著者らは, $\mathrm{Fe}_{2} \mathrm{O}_{3}$ と闰様に両性酸化物として挙動すると 考光られる $\mathrm{TiO}_{2}, \mathrm{Al}_{2} \mathrm{O}_{3}$ の理酸篮がラス中の珪酸陰イオン に及法す影響を赤外線吸収スペクトルの測定により考察 し，すで報告(2) (5)している。市た， $\mathrm{TiO}_{2} や \mathrm{Al}_{2} \mathrm{O}_{3}$ を 主体とした 2 元化合物やガラスについての赤外線吸収スへ クトルについては多くの報告がなされている。例光ば Roy ら ${ }^{(6)}$ によると, $\mathrm{Ti}^{4+}$ (oct.)の $\mathrm{Ti}^{4+}-\mathrm{O}^{2-}$ の伸縮振動は $500 \sim 650 \mathrm{~cm}^{-1}, \mathrm{Ti}^{4+}$ (tetr.)のそれは, $690 \sim 850 \mathrm{~cm}^{-1}$ そ されている。また $\mathrm{Al}_{2} \mathrm{O}_{3}$ については Schroeder ら(7)は, $\mathrm{Al}^{3+}$ (oct.)の $\mathrm{Al}^{3+}-\mathrm{O}^{2-}$ の伸縮振動は $740 \mathrm{~cm}^{-1}$ 付近火, $\mathrm{Al}^{3+}$ (tetr.)のそれは $775 〜 900 \mathrm{~cm}^{-1}$ に見出されると報告して いる。い寸゙れも $\mathrm{M}-\mathrm{O}\left(\mathrm{M}=\mathrm{Ti}^{4+}, \mathrm{Al}^{3+}\right)$ 伸縮振動の吸收率 は，酸素配位数が 6 配位から 4 配位にな礼ば高波数側一移 行している. $\mathrm{BaO}-\mathrm{Fe}_{2} \mathrm{O}_{3}$ 系は $\mathrm{Fe}_{2} \mathrm{O}_{3} 30 \mathrm{~mol} \%$ から $60 \mathrm{~mol} \%$ までの範囲で, splat quenchingによってガラス化した報 告(8)はあるが, $\mathrm{Fe}_{2} \mathrm{O}_{3}$ とアルカリ酸化物，アルカリ土類酸 化物の 2 元化合物やガラスについての赤外線吸収スペクト ルに関する報告は少ない，な拉，本実験では拄酸塩がラス 中での $\mathrm{Fe}^{3+}-\mathrm{O}^{2-}$ の主吸収带の酸素配位数による移行は, $\mathrm{Si}-\mathrm{O}$ 伸縮振動等の吸收強度が強いため， $\mathrm{SiO}_{2}$ を含む場合 は考察できなかった。

\section{II. 実験}

試料作成红 $\mathrm{SiO}_{2}$ として試薬特級石英砂を，アルカリ， アルカリ土類酸化物は特秝試薬の炭酸㙁， $\mathrm{Fe}_{2} \mathrm{O}_{3}$ は $99.9 \%$ の特級試薬を用いた，とれぞれを目的組成になるように精 科し，十分混合した後，融点が $1600^{\circ} \mathrm{C}$ 以下で容易にガラ ス化できるるのは手金ルッボで溶融，氷上にてルッボ外部 より急冷がラス化した，融点が $1600^{\circ} \mathrm{C}$ 以上の陚料，阽上 び容易にガラス化しない試料はPt-30\% Rh 線を抵抗体と するホットフィラメントにより溶融，高生ガスを用いた splat quenching ${ }^{(9)}$ 仙り急冷ガラス化した。

以上のよらにして作製した試料を，メノウ鉢を用いて， 約 $2 \mu$ 以下㳊破，その $0.5 \sim 1.5 \mathrm{mg}$ を $200 \mathrm{mg}$ の $\mathrm{KBr}$ 粉末をよく混合した後，約 $10 \mathrm{t} / \mathrm{cm}^{2}$ の日:力て銫剂に成型 した，湘走装圆は島津 IR-27 G で，测定波数範囲は 400〜 $1700 \mathrm{~cm}^{-1}$ である。

* 九州大学工学部咍金学教䇪(Department of Metallurgy, Faculty of Engineering, Kyushu University， Fukuoka)

**九州工業大学金属工学教室(Department of Metallurgy, Kyushu Institute of Technology, Kitakyushu)

***九州大学工学部材料開発工学教室(Department of Materials Science \& Technology, Kyushu University, Fukuoka) 


\section{III. 結 果}

\section{RO- , $\mathrm{R}_{2} \mathrm{O}-\mathrm{Fe}_{2} \mathrm{O}_{3}$ 系の化合物およびガラス質の赤外 線吸収スペクトル}

Fig.1 1 FeO, $\mathrm{Fe}_{2} \mathrm{O}_{3}, \mathrm{Fe}_{3} \mathrm{O}_{4}$ の赤外線吸收スペクトルを 示す。図に示すように, $\mathrm{FeO}$ の $\mathrm{Fe}^{2+}-\mathrm{O}^{2-}$ の主吸収带は 450 $\mathrm{cm}^{-1}$ 付近であり, $\mathrm{Fe}_{2} \mathrm{O}_{3}$ の $\mathrm{Fe}^{3+}$ は酸素 6 配位 8 面体の中 心に位置して扣り，その $\mathrm{Fe}^{3 *}$ (oct.)-O2-の主吸収带は555 $\mathrm{cm}^{-1}$, 委大副吸収带は $470 \mathrm{~cm}^{-1}$ に存在する. $\mathrm{Fe}_{3} \mathrm{O}_{4}$ は逆 スピネル構造をとり，Fe $\mathrm{Fe}^{2+}$ と， $\mathrm{Fe}^{3+}$ の些分が酸素 6 配位 8 面体の中心源 $\mathrm{Fe}^{3+}$ 半分が酸素4配位 4 面体の中心 に位置する. $\mathrm{Fe}_{3} \mathrm{O}_{4}$ は $\mathrm{Fe}^{3+}$ (oct.) $/ \mathrm{Fe}^{3+}$ (tetr.) =1 と考光 られるが，その主吸取带は約 $580 \mathrm{~cm}^{-1}$ 比り， $\mathrm{Fe}_{2} \mathrm{O}_{3}$ の $\mathrm{Fe}^{3+}-\mathrm{O}^{2-}$ の主吸取荤より高波数側一移行している。

Fig. $2 \mathrm{~K} \mathrm{Na}_{2} \mathrm{O} \cdot \mathrm{Fe}_{2} \mathrm{O}_{3}, \mathrm{~K}_{2} \mathrm{O} \cdot \mathrm{Fe}_{2} \mathrm{O}_{3}, 2 \mathrm{CaO} \cdot \mathrm{Fe}_{2} \mathrm{O}_{3}, \mathrm{CaO}$.

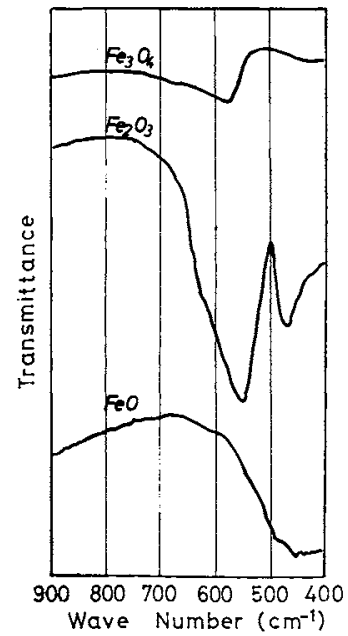

Fig.1 Infrared absorption spectra of $\mathrm{FeO}$, $\mathrm{Fe}_{3} \mathrm{O}_{4}$ and $\mathrm{Fe}_{2} \mathrm{O}_{3}$.

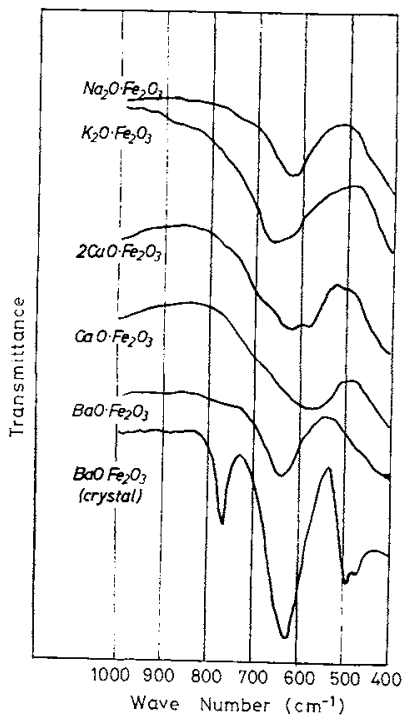

Fig.2 Infrared absorption spectra of $\mathrm{R}_{2} \mathrm{O}$. $\mathrm{Fe}_{2} \mathrm{O}_{3}, \mathrm{RO} \cdot \mathrm{Fe}_{2} \mathrm{O}_{3} \cdot$ (glasses)
$\mathrm{Fe}_{2} \mathrm{O}_{3}, \mathrm{BaO} \cdot \mathrm{Fe}_{2} \mathrm{O}_{3}$ のガラス誓試料の赤外線吸収スペクト ルを示した。一例として $\mathrm{BaO} \cdot \mathrm{Fe}_{2} \mathrm{O}_{3}$ の徐冷した結晶質と 考えられる試料のスペクトルも示している。図から明らか なように， $\mathrm{BaO} \cdot \mathrm{Fe}_{2} \mathrm{O}_{3}$ の徐冷試料枯 $770 \mathrm{~cm}^{-1}, 640 \mathrm{~cm}^{-1}$, $500 \mathrm{~cm}^{-1}, 475 \mathrm{~cm}^{-1}$ にするどいピークを示し, $\mathrm{Fe}^{3+}-\mathrm{O}^{2-}$ の 主吸收帯は $640 \mathrm{~cm}^{-1}$ にあると考えられる。一方 $\mathrm{BaO} \cdot \mathrm{Fe}_{2} \mathrm{O}_{3}$ の急冷試料はガラス質特有のbroadな昅取ピークを655 $\mathrm{cm}^{-1}$ 付近示している。他の系の徐冷試料も， $\mathrm{BaO} \cdot \mathrm{Fe}_{2} \mathrm{O}_{3}$ と同じくするどい吸收を示し，念泠試料は图のような broadな吸収带を示したＦig.2の收收带は，Fig.1に示 した $\mathrm{Fe}_{2} \mathrm{O}_{3}, \mathrm{Fe}_{3} \mathrm{O}_{4}$ の主财收帯と考文られ, $\mathrm{Fe}_{2} \mathrm{O}_{3}$ 中の $\mathrm{Fe}^{3+}$ は $\mathrm{Fe}^{3+}$ (oct.) で， $\mathrm{Fe}^{3+}-\mathrm{O}^{2-}$ の主吸收蒂が $555 \mathrm{~cm}^{-1}$ である のに此べると，いずれの吸収带もそのピークが高波数側一 移行している。 $\mathrm{K}_{2} \mathrm{O} \cdot \mathrm{Fe}_{2} \mathrm{O}_{3}$ では $665 \mathrm{~cm}^{-1}, \mathrm{Na}_{2} \mathrm{O} \cdot \mathrm{Fe}_{2} \mathrm{O}_{3}$ で は $625 \mathrm{~cm}^{-1}, \mathrm{BaO} \cdot \mathrm{Fe}_{2} \mathrm{O}_{3}$ では $650 \mathrm{~cm}^{-1}, \mathrm{CaO} \cdot \mathrm{Fe}_{2} \mathrm{O}_{3}$ では $585 \mathrm{~cm}^{-1}$ を示した。 $2 \mathrm{CaO} \cdot \mathrm{Fe}_{2} \mathrm{O}_{3}$ は $\mathrm{CaO} \cdot \mathrm{Fe}_{2} \mathrm{O}_{3}$ に比べて 高波数側へ移行し， $\mathrm{CaO} \cdot \mathrm{Fe}_{2} \mathrm{O}_{3}$ の示すピークと同じ 580 $\mathrm{cm}^{-1}$ にピークを示すが， $630 \mathrm{~cm}^{-1}$ に吸収ピークを示し ている。

このように $\mathrm{R}_{2} \mathrm{O} \cdot \mathrm{Fe}_{2} \mathrm{O}_{3}, \mathrm{RO} \cdot \mathrm{Fe}_{2} \mathrm{O}_{3}$ でRの陽イオンが変

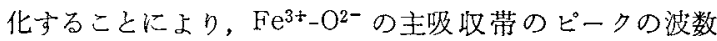
に変化がおこっている。高た $\mathrm{CaO}-\mathrm{Fe}_{2} \mathrm{O}_{3}$ の同じ系でも， $\mathrm{CaO} / \mathrm{Fe}_{2} \mathrm{O}_{3}$ の比が大きくなると， $\mathrm{Fe}^{3+}-\mathrm{O}^{2-}$ の主吸収帶の ピークは䯩波数側入移行している。このピークの移行は $\mathrm{Fe}^{3+}$ の酸素配位数の变化比よと推定され, $\mathrm{TiO}_{2}{ }^{(6)}$, $\mathrm{Al}_{2} \mathrm{O}_{3}{ }^{(7)}$ のガラスや化合物の赤外線吸収スペクトルの变化 から類推して，高波数側へのピークの移行は， $\mathrm{Fe}^{3+}$ の酸 素配位数が 6 から 4 亿移行すること対応し，また $\mathrm{Fe}^{3+5}$ の酸素陰イオンの重合度が增していることを䁕示してい $ろ^{(10)}$.

\section{2. $\mathrm{CaO}-, \mathrm{Na}_{2} \mathrm{O}-\mathrm{SiO}_{2}-\mathrm{Fe}_{2} \mathrm{O}_{3}$ 系の赤外線吸収スペクト ル}

理酸塩ガラスの赤外線吸収スペクトルは波数 1100〜900 $\mathrm{cm}^{-1}$ に大きな吸収帯を示すが，これは珪酸陰イオンの Si○伸縮振動 $\left(\nu_{3}\right)$ にる吸収であり，また $800 \sim 700 \mathrm{~cm}^{-1}$ の 吸収带は同じく伸繀振動 $\left(\nu_{1}\right)$ にる吸収, 約 $500 \sim 470 \mathrm{~cm}^{-1}$ の吸収帯は変角振動 $\left(\nu_{4}\right)$ によるもので㘯ると報告(11)されて いる。本報交では主として $\mathrm{Si}-\mathrm{O}$ 伸維振動 $\left(\nu_{3}\right)$ による吸収 带について检討し， $\mathrm{Fe}_{2} \mathrm{O}_{3}$ の珪酸陰イオンに及济す影響に ついて報告する。

$\mathrm{Si}-\mathrm{O}$ 伸絔振動 $\left(\nu_{3}\right)$ は赤外線領域の $800 \sim 1100 \mathrm{~cm}^{-1}$ K吸 収帯を示し, Saksena ${ }^{(12)}$ は多くの天然産鉱物の赤外線吸 収スペクトルの研究から，珪酸陰イオンの型を分類してい る. 著者ら ${ }^{(13)}$ はSaksena の研究結果打よび多くの2 元系 拄酸壏ガラス，またそのガラスの結晶化過程の赤外線吸収 スペクトルから，珪酸塩がラスでは， $890 \mathrm{~cm}^{-1}$ の吸収は $\mathrm{SiO}_{4}^{4-}$ の単一 4 面体, $930 \mathrm{~cm}^{-1}$ の吸收は $\mathrm{Si}_{2} \mathrm{O}_{7}^{6-}$ による吸 収であり，珪酸陰イオンの重合度が大きくなると高波数側 
へ移行し, $1100 \mathrm{~cm}^{-1}$ の吸収は 3 次元の網目構造の吸収で あると考劣ている。

(1) $\mathrm{CaO}-\mathrm{SiO}_{2}-\mathrm{Fe}_{2} \mathrm{O}_{3}$ 系の赤外線吸収スペクトル

$\mathrm{CaO}-\mathrm{SiO}_{2} 2$ 元系ガラスの赤外線吸收についてはすで 報告(13) している。皇こで本実験では $\mathrm{CaO}-\mathrm{SiO}_{2} 2$ 元䒺の珪 酸䧔イオンに及ぼす $\mathrm{Fe}_{2} \mathrm{O}_{3}$ の影響について検討を加えた。

Fig.3 $\mathrm{K} \mathrm{CaO} / \mathrm{SiO}_{2}=1$ K $\mathrm{Fe}_{2} \mathrm{O}_{3}$ を添加した系列の赤外 線吸収スペクトルを示した。図中の数字は添加した $\mathrm{Fe}_{2} \mathrm{O}_{3}$ の $\mathrm{mol} \%$ である. $\mathrm{Fe}_{2} \mathrm{O}_{3}$ を添加しない、 $\mathrm{CaO} \cdot \mathrm{SiO}_{2} 2$ 元系の 吸収スペクトルは $930 \mathrm{~cm}^{-1}$ と $1030 \mathrm{~cm}^{-1}$ 付近飞吸收を示

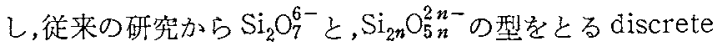
anion 構造の珪酸陰イオンが主体で荡ると推定される。こ の 2 元系比 $\mathrm{Fe}_{2} \mathrm{O}_{3}$ を源加すると $930 \mathrm{~cm}^{-1}$ と $1030 \mathrm{~cm}^{-1}$ の 二つの吸収ピークは一つの吸收ピークに移行し, 約 20 $\mathrm{mol} \% \mathrm{Fe}_{2} \mathrm{O}_{3}$ の涯加により, $960 \mathrm{~cm}^{-1}$ ○ $\mathrm{Si}_{n} \mathrm{O}_{3 n}^{2 n-}(n=3 \sim$ 8)のリング状の珄酸陰イオンと推定される吸収ピークを示 す. さらに $\mathrm{Fe}_{2} \mathrm{O}_{3}$ の源加最を增加しても $960 \mathrm{~cm}^{-1}$ 付近の 吸収ピークの移行はなく，珪酸除イオンの型状に大きな変 化がないと推定される。

Fig. 4 に CaO/ $/ \mathrm{SiO}_{2}=2 / 3 \mathrm{~K} \mathrm{Fe}_{2} \mathrm{O}_{3}$ を添加した系列の赤 外線吸収スペクトルを示した. $\mathrm{CaO} / \mathrm{SiO}_{2}=2 / 3$ の 2 元系は $1020 \mathrm{~cm}^{-1}$ k主吸收ピークを，930 $\mathrm{cm}^{-1}$ 付近に副吸収ピ一 クを示し, discrete anion 構造の珪酸陰イオンと $\mathrm{Si}_{2} \mathrm{O}_{7}^{6-}$ が主体であると考兄られる。この系に $\mathrm{Fe}_{2} \mathrm{O}_{3}$ を源加する 之 $930 \mathrm{~cm}^{-1}$ 付近の吸收ビークは吸収波数は変化せず吸収 強度が強くなり，一方， discrete anion 構造の吸収ピーク と考党られる $1020 \mathrm{~cm}^{-1}$ 付近の吸收ピークは低波数䁌へ移 行し，大きな玨酸陰イオンが $\mathrm{Fe}_{2} \mathrm{O}_{3}$ の派加に上り切断さ れ，小さな嵁酸イオンになっていくことを示している。 $\mathrm{Fe}_{2} \mathrm{O}_{3}$ を $15 \mathrm{~mol} \%$ 添加すると約 $930 \mathrm{~cm}^{-1}$ の $\mathrm{Si}_{2} \mathrm{O}_{7}^{6-}$ 之若

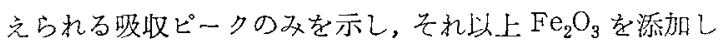

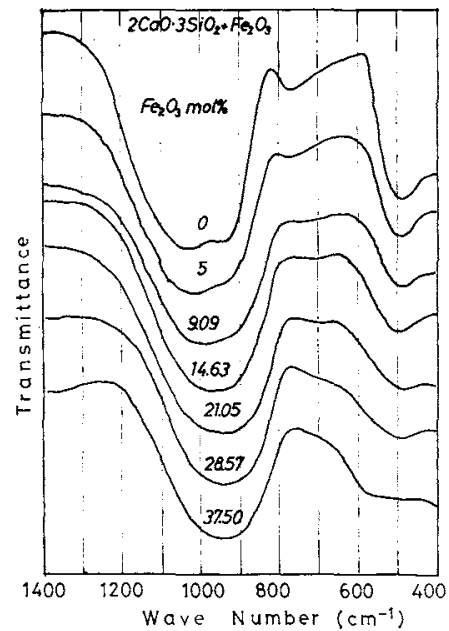

Fig.4 Infrared absorption spectra of CaO$\mathrm{SiO}_{2}-\mathrm{Fe}_{2} \mathrm{O}_{3}$ glasses. $\left(\mathrm{CaO} / \mathrm{SiO}_{2}=2 / 3\right.$ )

ても，吸収ピークの移行はみられず,珪酸陰イオン櫣造には 大きな変化泣なく， $\mathrm{Si}_{2} \mathrm{O}_{7}^{6-}$ が主体と推定される。

Fig. 3, Fig.4 の比較から, $\mathrm{CaO} / \mathrm{SiO}_{2}=1$ の系列では約 20 $\mathrm{mol} \% \mathrm{Fe}_{2} \mathrm{O}_{3}$ 添加玉で吸収ピークはほるやか移行し、リ ング状珪酸陰イオンが主体となっている。一方， $\mathrm{CaO} / \mathrm{SiO}_{2}$ $=2 / 3$ の系列は約 $15 \mathrm{~mol} \% \mathrm{Fe}_{2} \mathrm{O}_{3}$ 添加までかなり念激な吸 收ピークの移行を示し， $\mathrm{Si}_{2} \mathrm{O}_{7}^{6-}$ の珪酸陰イオンが主体とな っている.このことは, $\mathrm{Fe}_{2} \mathrm{O}_{3}$ は $\mathrm{CaO} / \mathrm{SiO}_{2}=1$ の系列に対 してよりも， $\mathrm{CaO} / \mathrm{SiO}_{2}=2 / 3$ の系列に対して,ょり network modifierとして作用していることを示している。

\section{(2) $\mathrm{Na}_{2} \mathrm{O}-\mathrm{SiO}_{2}-\mathrm{Fe}_{2} \mathbf{O}_{3}$ 系の赤外線吸取スペクトル}

$\mathrm{Na}_{2} \mathrm{O}-\mathrm{SiO}_{2} 2$ 元系の赤外線吸収スペクトルについてはす で飞報告している ${ }^{(13)}$. Fig.5 に $\mathrm{Na}_{2} \mathrm{O} / \mathrm{SiO}_{2}=1$ の組成の試 料に $\mathrm{Fe}_{2} \mathrm{O}_{3}$ を添加した䒺列の赤外線吸収スペクトルを示

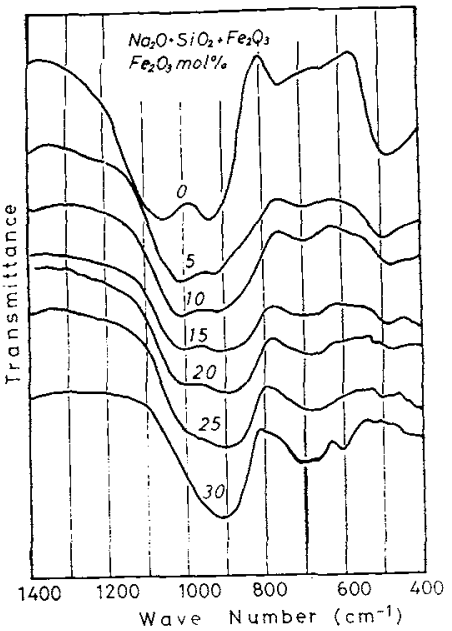

Fig.5 Infrared absorption spectra of $\mathrm{Na}_{2} \mathrm{O}$ $\mathrm{Fe}_{2} \mathrm{O}_{3}$ glasses. $\left(\mathrm{Na}_{2} \mathrm{O} / \mathrm{SiO}_{2}=1\right)$
Fig.3 Infrared absorption spectra of $\mathrm{CaO}$

$\mathrm{SiO}_{2}-\mathrm{Fe}_{2} \mathrm{O}_{3}$ glasses. $\left(\mathrm{CaO} / \mathrm{SiO}_{2}=1\right.$ )

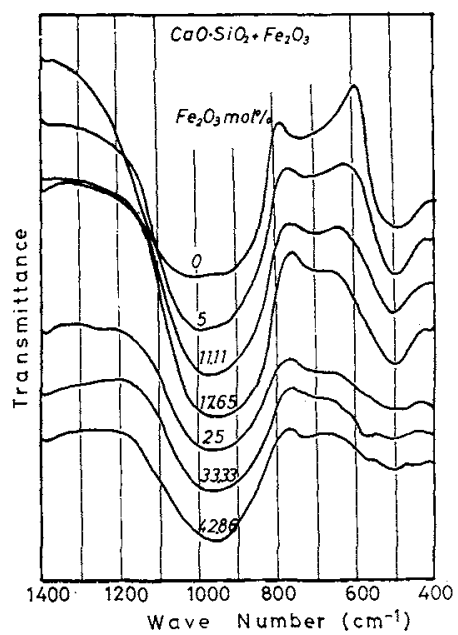


す. $\mathrm{Na}_{2} \mathrm{O} \cdot \mathrm{SiO}_{2}$ ガラスの理酸㓌イオンは $930 \mathrm{~cm}^{-1}$ そ 1030 $\mathrm{cm}^{-1}$ に吸取と゚ークを示すことから $\mathrm{Si}_{2} \mathrm{O}_{7}^{6-}$ とdiscrete anion 權造の $\mathrm{Si}_{2 n} \mathrm{O}_{5 n}^{2 n-}$ が主体と洘学られる。この 2 元系 に $\mathrm{Fe}_{2} \mathrm{O}_{3}$ を泒加すると， $\mathrm{Fe}_{2} \mathrm{O}_{3} 25 \mathrm{~mol} \%$ まで吸叹ピー クは $1030 \mathrm{~cm}^{-1}$ が $1000 \mathrm{~cm}^{-1}, 930 \mathrm{~cm}^{-1}$ が $890 \mathrm{~cm}^{-1}$ へ之移 行して, discrete anion 構造の琒酸陰イオンの多少の崩壊 と, $\mathrm{Si}_{2} \mathrm{O}_{7}^{6-}$ の $\mathrm{SiO}_{4}^{4-}$ 単一 4 面体への移行がみら礼るが，吸 収スペクトルの型には大きな变化は生しない。つまり $\mathrm{Fe}_{2} \mathrm{O}_{3}$ を $25 \mathrm{~mol} \%$ 安で添加してむ， $\mathrm{CaO} / \mathrm{SiO}_{2}=1$ の系列 に此へて，珪酸陰イオンは大きく变化していないと考光ら れる。しかし， $\mathrm{Fe}_{2} \mathrm{O}_{3}$ を $30 \mathrm{~mol} \%$ 添加すると，吸収ピークは $920 \mathrm{~cm}^{-1}$ 付近に收斂し, $25 \mathrm{~mol} \%$ から $30 \mathrm{~mol} \% \mathrm{Fe}_{2} \mathrm{O}_{3}$ の 間に拄酸除イオンの構造に大きな变化が抗こり, discrete anion 構造の㫜酸陰イオンが崩填し， $\mathrm{Si}_{2} \mathrm{O}_{7}^{6-}$ の珪酸陰イオ ンが主体となる。さらに $35,40 \mathrm{~mol} \%$ と $\mathrm{Fe}_{2} \mathrm{O}_{3}$ を添加し てる吸収ピークに移行はみられない。

以上のように $\mathrm{Fe}_{2} \mathrm{O}_{3}$ を $\mathrm{Na}_{2} \mathrm{O} / \mathrm{SiO}_{2}=1$ に添加しても，25 $\mathrm{mol} \% \mathrm{Fe}_{2} \mathrm{O}_{3}$ 付近までは吸収スペクトルに大きな変化はな く, 珪酸陰イオンの構造の変化は小さい. しかし， $\mathrm{Fe}_{2} \mathrm{O}_{3}$ を約 $30 \mathrm{~mol} \%$ 添加することにより，理酸陰イオンの構造 は大きく变化し， $\mathrm{Si}_{2} \mathrm{O}_{7}^{6-}$ が主体となると考えられる。 Fig.3に示した $\mathrm{CaO} / \mathrm{SiO}_{2}=1$ の系列のスペクトルと比較 すると, $\mathrm{Fe}_{2} \mathrm{O}_{3}$ は $\mathrm{Na}_{2} \mathrm{O} / \mathrm{SiO}_{2}=1$ では， $\mathrm{CaO} / \mathrm{SiO}_{2}=1$ と異 なった影響を理酸陰イオンに及济すことが考えられる。

Fig. 6 に $\mathrm{Na}_{2} \mathrm{O} / \mathrm{SiO}_{2}=2 / 3$ の系列飞 $\mathrm{Fe}_{2} \mathrm{O}_{3}$ を添加した系 列の赤外線吸収スペクトルを示した. $2 \mathrm{Na}_{2} \mathrm{O} .3 \mathrm{SiO}_{2}$ ガ ラスは, $1065 \mathrm{~cm}^{-1}$ と $970 \mathrm{~cm}^{-1}$ に吸收ピークを示し, $\mathrm{Si}_{16} \mathrm{O}_{36}^{8-}$ 等の立体跂状の球酸陰イオンと $\mathrm{Si}_{n} \mathrm{O}_{3 n}^{2 n-}(n=3 \sim 8)$ の構造をるつリング状球酸陰イオンが主体と考光られる。 この 2 元系化 $\mathrm{Fe}_{2} \mathrm{O}_{3}$ 添加すると $\mathrm{Fe}_{2} \mathrm{O}_{3} 15 \mathrm{~mol} \%$ までは， $1065 \mathrm{~cm}^{-1}$ か $1020 \mathrm{~cm}^{-1}$ k, $970 \mathrm{~cm}^{-1}$ か $920 \mathrm{~cm}^{-1}$ へと移 行して, 理酸陰イオンは立体鼓状の構造からdiscrete

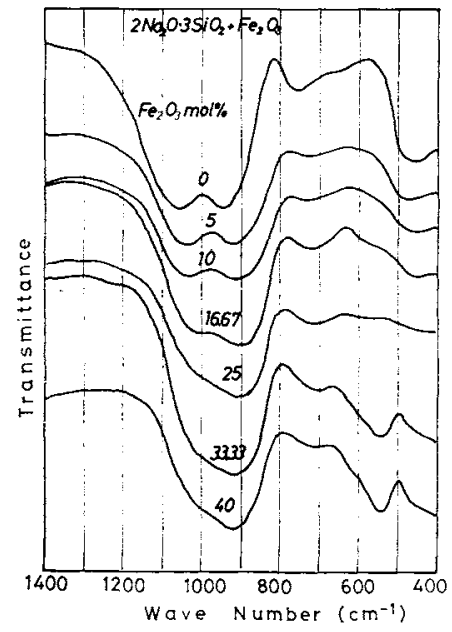

Fig.6 Infrared absorption spectra of $\mathrm{Na}_{2} \mathrm{O}-$ $\mathrm{SiO}_{2}-\mathrm{Fe}_{2} \mathrm{O}_{3}$ glasses. $\left(\mathrm{Na}_{2} \mathrm{O} / \mathrm{SiO}_{2}=2 / 3\right)$ anion 構造，リング状構造から $\mathrm{Si}_{2} \mathrm{O}_{7}^{6-}$ へ徐タに移行して いるが，吸收ピークの型には大きな変化はみられない、し かし， $\mathrm{Fe}_{2} \mathrm{O}_{3}$ を $25 \mathrm{~mol} \%$ 添加すると主吸收ピークは約 920 $\mathrm{cm}^{-1}$ 付近を示し，大きな理酸陰イオンが崩境し， $\mathrm{Si}_{2} \mathrm{O}_{7}^{6-}$ が主体となっている。ささらに $\mathrm{Fe}_{2} \mathrm{O}_{3}$ を淩加すると，よりそ の傎向を強く示し， $40 \mathrm{~mol} \% \mathrm{Fe}_{2} \mathrm{O}_{3}$ 添加では $\mathrm{Si}_{2} \mathrm{O}_{7}^{6-}$ が主 体となる吸収ピークを示していると考えられるＦig.5 に 示した $\mathrm{Na}_{2} \mathrm{O} / \mathrm{SiO}_{2}=1$ の系列と比較して，Fig.6亿示した $\mathrm{Na}_{2} \mathrm{O} / \mathrm{SiO}_{2}=2 / 3$ の系列では $\mathrm{SiO}_{2}$ 含有量が多い氏すかか子 らず, 約 $25 \mathrm{~mol} \% \mathrm{Fe}_{2} \mathrm{O}_{3}$ 添加により， $\mathrm{Si}_{2} \mathrm{O}_{7}^{6-}$ と考党られ る $930 \mathrm{~cm}^{-1}$ の吸收ピークに収斂している。

\section{IV. 考察}

赤外線吸取スペクトルのピークシフトと配位の関保につ いて, Danchill, Roy ${ }^{(18)} ら$ は， $\mathrm{M}-\mathrm{O}(\mathrm{M}=$ 陵イオン) 伸縮モ 一ドに相当する主吸収带は配位が低次になると高波数側へ 動くことを報告している。委たTarte ${ }^{(10)}$ は $\mathrm{Al}_{2} \mathrm{O}_{3}, \mathrm{TiO}_{2}$ を 含さガラスの赤外線吸収スペクトルの研究から一般的な説

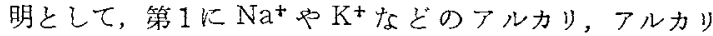
土類金属䣒イオンによって与兄られる bond は約 $500 \mathrm{~cm}^{-1}$ 以上の赤外線領域では固有の吸収スペクトルを示さない, 第 2 に配位数が小さい㤬ど bond の長さが短くなり振動数 は高くなる，第 3 に独立した配位群上り重合状態にある配

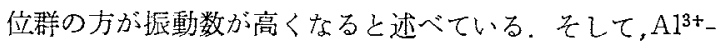
$\mathrm{O}^{2-}, \mathrm{Ti}^{4+}-\mathrm{O}^{2-}$ の蚛縮振動の吸收ピークのシフトと $\mathrm{Al}^{3+}$, Ti行の酸素配位数の関係を報告している。 また Schroeder ら (7)は多くの無機アルミン酸塭の絓晶の赤外線吸収スペク トルから $\mathrm{Al}^{13+}-\mathrm{O}^{2-}$ の伸縮振動之酸素配位数の関係示示し， Tarte らの考え方と一致した結果を示している.

以上の考方方をとに， $\mathrm{Fe}_{2} \mathrm{O}_{3}$ を主体とするがラス質試 料に乱计る $\mathrm{Fe}^{3+}-\mathrm{O}^{2-}$ の主吸收带のピークシフトを酸素配 位数の变化から考察する。

\section{1. $\mathbf{F e}^{3+}-\mathbf{O}^{2-}$ の主吸収带のピークシフト}

ガラス質試料中の $\mathrm{Fe}^{3+}-\mathrm{O}^{2-}$ 主吸収帯は $580 \sim 665 \mathrm{~cm}^{-1}$ に測定された。 $\mathrm{R}_{2} \mathrm{O} \cdot \mathrm{Fe}_{2} \mathrm{O}_{3}, \mathrm{RO} \cdot \mathrm{Fe}_{2} \mathrm{O}_{3}$ 系ガラス質の中の $\mathrm{Fe}^{3+}-\mathrm{O}^{2-}$ の主吸收带のピーク波数を $\mathrm{R}_{2} \mathrm{O}, \mathrm{RO}$ の塩基性が 強いと考光られる順に Table 1 以ま之めた，表中心は隄 イオンRの oxygen-ion attraction ${ }^{(14)}\left(2 z / a^{2} ; z=\right.$ 陽 イオ ンの電荷， $a=$ 陽イオンと酸素イオンの半径の和)示し た。

$2 \mathrm{CaO} \cdot \mathrm{Fe}_{2} \mathrm{O}_{3}$ の化合物について，メスバウアースペクト ルの测定より $\mathrm{Fe}^{3+}$ は $\mathrm{Fe}^{3+}$ (tetr.)/ $/ \mathrm{Fe}^{3+}$ (oct.)=1という 報告(15)がある。本実験でがラス質の $2 \mathrm{CaO} \cdot \mathrm{Fe}_{2} \mathrm{O}_{3}$ る $\mathrm{Broad}$ な吸収帯であるが，580 $\mathrm{cm}^{-1}$ と $630 \mathrm{~cm}^{-1}$ に吸収ピークを 示している。 また，緒論で述べた $\mathrm{Al}_{2} \mathrm{O}_{3}$ や $\mathrm{TiO}_{2}$ の $\mathrm{Al}^{3+}$ $\mathrm{O}^{2-}, \mathrm{Ti}^{4+}-\mathrm{O}^{2-}$ の酸素配位数による吸収ピークの変化は, 4 配位の方が高波数側に放ることなどから推定すると， 
Table 1 The wave number of $\mathrm{Fe}^{3+}-\mathrm{O}^{2-}$ in $\mathrm{R}_{2} \mathrm{O} \cdot \mathrm{Fe}_{2} \mathrm{O}_{3}, \mathrm{RO} \cdot \mathrm{Fe}_{2} \mathrm{O}_{3}$ glasses.

\begin{tabular}{l|c|c|c}
\hline & $2 z / a^{2}$ & $\begin{array}{c}\text { Peak } \\
\text { wave number } \\
\text { of } \mathrm{Fe}^{3+}-\mathrm{O} \\
\left(\mathrm{cm}^{-1}\right)\end{array}$ & $\begin{array}{c}\text { Oxygen } \\
\text { coordination } \\
\text { number of } \mathrm{Fe}^{3+}\end{array}$ \\
\hline $\mathrm{K}_{2} \mathrm{O} \cdot \mathrm{Fe}_{2} \mathrm{O}_{3}$ & 0.27 & 665 & $\mathrm{Fe}^{3+}$ (tetr.) \\
$\mathrm{Na}_{2} \mathrm{O} \cdot \mathrm{Fe}_{2} \mathrm{O}_{3}$ & 0.35 & 625 & $\mathrm{Fe}^{3+}$ (tetr.) \\
$\mathrm{BaO} \cdot \mathrm{Fe}_{2} \mathrm{O}_{3}$ & 0.51 & 650 & $\mathrm{Fe}^{3+}$ (tetr.) \\
$\mathrm{CaO} \cdot \mathrm{Fe}_{2} \mathrm{O}_{3}$ & 0.69 & 585 & $\mathrm{Fe}^{3+}$ (oct.) \\
$2 \mathrm{CaO} \cdot \mathrm{Fe}_{2} \mathrm{O}_{3}$ & & 580 & $\mathrm{Fe}^{3+}$ (oct.) \\
& 630 & $\mathrm{Fe}^{3+}$ (tetr.) \\
\hline
\end{tabular}

$580 \mathrm{~cm}^{-1}$ 付近の収収ピークは $\mathrm{Fe}^{3+}$ (oct.) $-\mathrm{O}^{2-}, 630 \mathrm{~cm}^{-1}$ 付近の吸收ピークは $\mathrm{Fe}^{3+}$ (tetr.) - $\mathrm{O}^{2-}$ の吸収ピークと推定 される。

$\mathrm{Fe}_{2} \mathrm{O}_{3}$ は $\mathrm{Al}_{2} \mathrm{O}_{3}$ と同様に，酸素 4 配位 4 面体を形成与る 時，陽電荷が 1 価と，酸素イオンが 1 值不足し，他の塩基 性酸化物から補允してもらう必要がある(16). そこで, 強 い盐基性を示す酸化物の存在により，Fe $\mathrm{F}^{3+}$ は酸素 4 配位 4 面体を形成することが可能になる．Table 1 に示したよ 亏に, $\mathrm{R}_{2} \mathrm{O} \cdot \mathrm{Fe}_{2} \mathrm{O}_{3}$ では $\mathrm{K}_{2} \mathrm{O}$ の方が $\mathrm{Na}_{2} \mathrm{O}$ より壏基性で $\mathrm{Fe}^{3+}-\mathrm{O}^{2-}$ の晊取ピークは高波数を示し，また $\mathrm{RO} \cdot \mathrm{Fe}_{2} \mathrm{O}_{3}$ で は $\mathrm{BaO}$ の方が $\mathrm{CaO}$ より䆝基性で, $\mathrm{Fe}^{3+}-\mathrm{O}^{2-}$ の吸收ピー クは $\mathrm{BaO}$ 系が $650 \mathrm{~cm}^{-1}$ で $\mathrm{Fe}^{3+}$ (tetr.)-O2- の吸収, $\mathrm{CaO}$ 系が580 $\mathrm{cm}^{-1}$ で $\mathrm{Fe}^{3+}$ (oct.)-O2-の吸収を示していると推 定される。また $\mathrm{CaO}-\mathrm{Fe}_{2} \mathrm{O}_{3}$ 系でる， $\mathrm{CaO} \cdot \mathrm{Fe}_{2} \mathrm{O}_{3}$ では $\mathrm{Fe}^{3+}$ は $\mathrm{Fe}^{3+}$ (oct.) 示しているが, $2 \mathrm{CaO} \cdot \mathrm{Fe}_{2} \mathrm{O}_{3}$ では $630 \mathrm{~cm}^{-1}$ の $\mathrm{Fe}^{3+}$ (tetr.)と $580 \mathrm{~cm}^{-1}$ の $\mathrm{Fe}^{3+}$ (oct.)と推定される吸 取ピークを示している。このことから $\mathrm{Fe}^{3+}$ の酸素配位数 は, $\mathrm{R}_{2} \mathrm{O}, \mathrm{RO}$ の塭基性酸化物の塩基度と $\mathrm{Fe}_{2} \mathrm{O}_{3} /\left(\mathrm{R}_{2} \mathrm{O}, \mathrm{RO}\right)$ の比によって変化すると推定され，塩基性が強い組成では $\mathrm{Fe}^{3+}$ (tetr.)が主体であり， $\mathrm{Fe}_{2} \mathrm{O}_{3}$ 含量が増加し， $\mathrm{Fe}_{2} \mathrm{O}_{3} /$ $\left(\mathrm{R}_{2} \mathrm{O}, \mathrm{RO}\right)$ の值が大きくなると $\mathrm{Fe}^{3+}$ (oct.)が増加すると考 党られ。

以上, $\mathrm{Fe}^{3+}-\mathrm{O}^{2-}$ の主吸収帯を酸素配位数の変化で矛盾 なく説明できる。のことから， $\mathrm{R}_{2} \mathrm{O} \cdot \mathrm{Fe}_{2} \mathrm{O}_{3}, \mathrm{RO} \cdot \mathrm{Fe}_{2} \mathrm{O}_{3}$ の 示す $550 \sim 650 \mathrm{~cm}^{-1}$ の吸収は $\mathrm{Fe}^{3+}-\mathrm{O}^{2-}$ の伸縮振動の主吸 収帯と推定でさる。

\section{2. $\mathrm{Fe}_{2} \mathrm{O}_{3}$ の珪酸陰イオンへの影響}

$\mathrm{N}-1$ に考察したよ 5 に, $\mathrm{R}_{2} \mathrm{O}, \mathrm{RO}$ の塩基度と $\mathrm{Fe}_{2} \mathrm{O}_{3} /$ $\left(\mathrm{R}_{2} \mathrm{O}, \mathrm{RO}\right)$ の比によって $\mathrm{Fe}^{3+}$ の酸素配位数に変化が見ら れた。珪酸程ガラス中での $\mathrm{Fe}^{3+}$ も, 塩基度と $\mathrm{Fe}_{2} \mathrm{O}_{3} /\left(\mathrm{R}_{2} \mathrm{O}\right.$ ， RO)の比によって酸䒺配位数が变化し, 珪酸陰イホンに 異った影響を与えることが推定できる。

酸素 4 配位 4 面体の中心に位置する $\mathrm{Fe}^{3 \div}$ (tetr.)は，酸 素錯陰イオンを形成し，珪酸陰イオンには大きな作用を示 さないと考えられる。一方，酸素 6 配位 8 面体の中心以位 置する $\mathrm{Fe}^{3+}$ (oct.) は陽イオンとして等動し，珪酸陰イオ ンを切断する，いわゆる network modifierとして作用
すると考えられる。

Fig.3,Fig.4,Fig.5およびFig.6に示した赤外線吸収

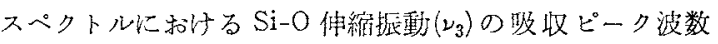
の变化と， $\mathrm{Fe}_{2} \mathrm{O}_{3}$ 含量の哭係を Fig.7に示した。図から 明らかなよ $5 \mathrm{~K} \mathrm{CaO} / \mathrm{SiO}_{2}=2 / 3$ は $15 \mathrm{~mol} \% \mathrm{Fe}_{2} \mathrm{O}_{3}, \mathrm{CaO} /$ $\mathrm{SiO}_{2}=1$ は $20 \mathrm{~mol} \% \mathrm{Fe}_{2} \mathrm{O}_{3}, \mathrm{Na}_{2} \mathrm{O} / \mathrm{SiO}_{2}=2 / 3$ は $25 \mathrm{~mol} \%$ $\mathrm{Fe}_{2} \mathrm{O}_{3}, \mathrm{Na}_{2} \mathrm{O} / \mathrm{SiO}_{2}=1$ では $30 \mathrm{~mol} \% \mathrm{Fe}_{2} \mathrm{O}_{3}$ 付近でそれぞれ 吸収ピークは収钽している、このことを塩基度から考える と, 酸性が強い組成と考克方孔る $\mathrm{CaO} / \mathrm{SiO}_{2}=2 / 3$ の系列 に添加された $\mathrm{Fe}_{2} \mathrm{O}_{3}$ の大头が, network modifier として 作用し，Fe $\mathrm{F}^{3+}$ (oct.) として存在していると推定される。一 方, 塩基性が強いと考光られる $\mathrm{Na}_{2} \mathrm{O} / \mathrm{SiO}_{2}=1$ の系列に添 加された $\mathrm{Fe}_{2} \mathrm{O}_{3}$ は $\mathrm{Fe}_{2} \mathrm{O}_{5}^{4-}$ 等の酸素釭陰イオンを形成し， 珪酸陰イオンに作用しないむのと推定される。

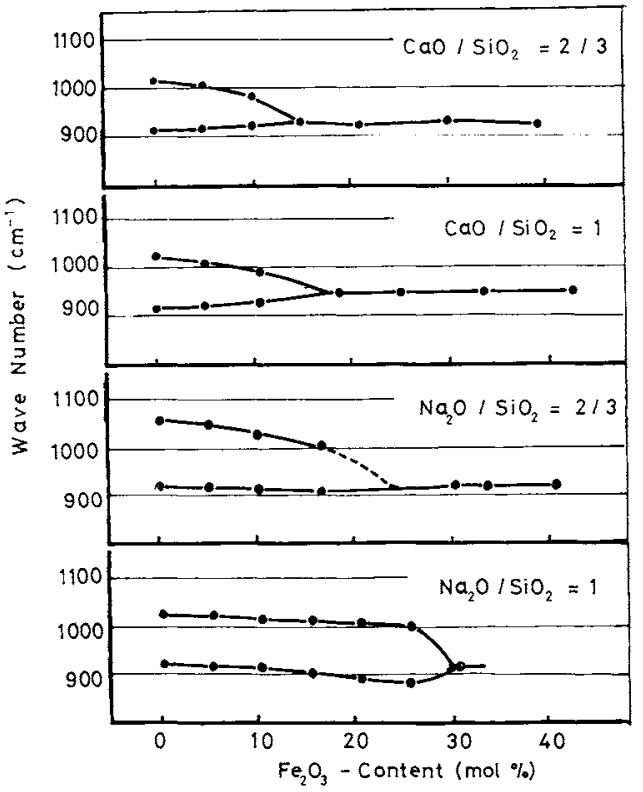

Fig.7 Relation between the wave number of peak ( $\mathrm{Si}-\mathrm{O}$ ) and $\mathrm{Fe}_{2} \mathrm{O}_{3}$ content.

また $\mathrm{Fe}_{2} \mathrm{O}_{3} /\left(\mathrm{R}_{2} \mathrm{O}, \mathrm{RO}\right)$ の比を考光ると $\mathrm{CaO}-\mathrm{SiO}_{2}$ 系で は，2つの系列と舟に $\mathrm{Fe}_{2} \mathrm{O}_{3} / \mathrm{CaO} \fallingdotseq 1 / 2$ で吸収ピークは取

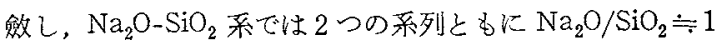
で吸收ピークは收斂している。この組成での変化について Frischat 5 (17)はFeイオンを含むアルカリ珪酸塩がラス のメスバゥアー效果の測定から， $\mathrm{Fe}^{3+} /\left(\mathrm{Na}^{+}+1 / 2 \mathrm{Ca}^{2+}\right) \fallingdotseq$ 1 K扎いて $\mathrm{Fe}^{3+}$ イオンの isomer shift が変化することを 認め, $\mathrm{Fe}^{3+}$ の酸素配位数が変化する結果であるとしてい る.また $\mathrm{Fe}^{3+} /\left(\mathrm{Na}^{+}+1 / 2 \mathrm{Ca}^{2+}\right)<1 の \mathrm{Fe}^{3+}$ が少ない領域 では酸素を4配位すると推定していることから，本実験で 6 $\mathrm{Fe}^{3+}$ の酸素配位数は $\mathrm{Fe}_{2} \mathrm{O}_{3} / \mathrm{CaO}, \mathrm{Fe}_{2} \mathrm{O}_{3} / \mathrm{Na}_{2} \mathrm{O}$ の比に よって变化し, $\mathrm{Fe}_{2} \mathrm{O}_{3} / \mathrm{CaO} \fallingdotseq 1 / 2$ 扎よび $\mathrm{Fe}_{2} \mathrm{O}_{3} / \mathrm{Na}_{2} \mathrm{O} \fallingdotseq 1$ の 組成で， $\mathrm{Fe}^{3+}$ の酸素配位数が変化し， $\mathrm{Fe}_{2} \mathrm{O}_{3}$ が多くなると 
$\mathrm{Fe}^{3+}$ (oct.)が多くなり，珪酸陰イオンに network modifier として作用するるのと推定される。

次に $F \mathrm{e}^{3+}$ の酸素配位数の䁘基度による変化を見るため K，広い組成簛国でガラス化できる $\mathrm{Na}_{2} \mathrm{O}-\mathrm{SiO}_{2}-\mathrm{Fe}_{2} \mathrm{O}_{3}$ 系 で, $\mathrm{Na}_{2} \mathrm{O}-\mathrm{SiO}_{2} 2$ 元系执よび $\mathrm{Na}_{2} \mathrm{O}-\mathrm{SiO}_{2}+10 \mathrm{~mol} \% \mathrm{Fe}_{2} \mathrm{O}_{3}$ の3元系到 $\mathrm{Na}_{2} \mathrm{O} / \mathrm{SiO}_{2}$ の比孝同一にして比较した赤外線 吸収スペクトル戍をFig.8に示した。

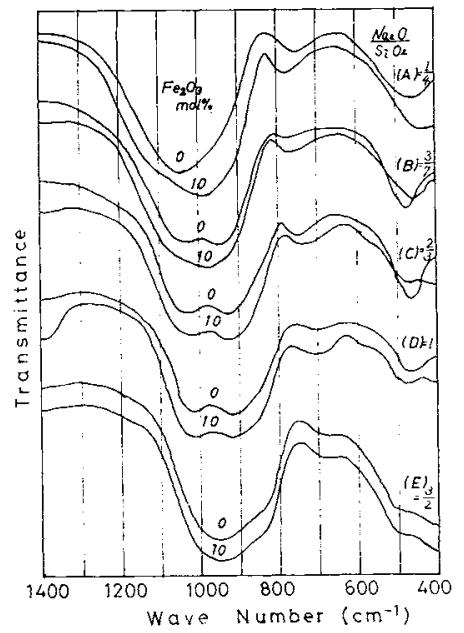

Fig.8 Infrared absorption spectra of $\mathrm{Na}_{2} \mathrm{O}-\mathrm{SiO}_{2}$, $\mathrm{Na}_{2} \mathrm{O}-\mathrm{SiO}_{2}+\mathrm{Fe}_{2} \mathrm{O}_{3}(10 \mathrm{~mol} \%)$ glasses.

図に和いて，(A)は $\mathrm{Na}_{2} \mathrm{O} / \mathrm{SiO}_{2}=1 / 4$ の 2 元系ガラスと をの組成に $10 \mathrm{~mol} \% \mathrm{Fe}_{2} \mathrm{O}_{3}$ を添加したガラスの赤外線吸 收スペクトルである. (A), (B)，(C) …...の順に $\mathrm{Na}_{2} \mathrm{O} / \mathrm{SiO}_{2}$ の比は大きなっている。図から明らかなように(E)，(D) の $\mathrm{Na}_{2} \mathrm{O}$ が多い領域では， $\mathrm{Fe}_{2} \mathrm{O}_{3}$ は理酸陰イオンに大きな 影暗を与えないと考えられる。しかし(B)，(A)のよ5に $\mathrm{SiO}_{2}$ が多くなると， $\mathrm{Fe}_{2} \mathrm{O}_{3}$ は珪酸陰イオンに作用し（A) では $\mathrm{Fe}_{2} \mathrm{O}_{3} 10 \mathrm{~mol} \%$ 添加により，1060 $\mathrm{cm}^{-1}$ の立体涉状が 主体の珪酸陰イオンが 970 990 $\mathrm{cm}^{-1}$ のリング状の珪酸陰 イオンになっている。

このように $\mathrm{Na}_{2} \mathrm{O} の$ 多い領域では $\mathrm{Fe}_{2} \mathrm{O}_{3}$ は球酸陰イオ ンの形状に大きな作用を与えず, $\mathrm{Fe}^{3+}$ は $\mathrm{F} \mathrm{e}^{3+}$ (tetr.)が大 部分であると考えられるが, $\mathrm{SiO}_{2}$ の多い領域では network modifierとして作用し，Fe $\mathrm{Fe}^{3+} \mathrm{Fe}^{3+}$ (oct.)の割合が増加 したる推定される。

\section{V. 結言}

(1) $\mathrm{RO} \cdot \mathrm{Fe}_{2} \mathrm{O}_{3}, \mathrm{RO} \cdot \mathrm{Fe}_{2} \mathrm{O}_{3}$ 系ガラス質の試料の赤外線吸 收スペクトルから， $\mathrm{Fe}^{3+}-\mathrm{O}^{2-}$ の主吸收帯は酸素配位数によ
り変化し, $\mathrm{Fe}^{3+}$ (tetr.) $-\mathrm{O}^{2-}$ は 625〜665 $\mathrm{cm}^{-1}, \mathrm{Fe}^{3+}$ (oct.)$\mathrm{O}^{2-}$ は $580 \mathrm{~cm}^{-1}$ 付近に吸収ピークを示した。

(2) $\mathrm{Fe}_{2} \mathrm{O}_{3}$ \& $\mathrm{TiO}_{2}, \mathrm{Al}_{2} \mathrm{O}_{3}$ と同様に両性酸化物で, $\mathrm{Fe}^{3+}$ は酸素 4 配位 4 面体の中心 $\left(\mathrm{Fe}^{3+}(\mathrm{tetr}\right.$.$) ) と酸素 6$ 配位 8 面 体( $\mathrm{Fe}^{3+}$ (oct.))の中心の双方に位置できると考点られる。

(3) $\mathrm{Fe}^{3+}$ (oct.) $/ \mathrm{Fe}^{3+}$ (tetr.) の比は塩基度と $\mathrm{Fe}_{2} \mathrm{O}_{3}$ / $\left(\mathrm{R}_{2} \mathrm{O}, \mathrm{RO}\right)$ O比によって左右され, 塩基性が強い領域では $\mathrm{Fe}^{3+}$ (tetr.)が主であり，变た $\mathrm{Fe}_{2} \mathrm{O}_{3}$ が堌加し， $\mathrm{Fe}_{2} \mathrm{O}_{3} /\left(\mathrm{R}_{2} \mathrm{O}\right.$ ， RO)の值が大きくなると $\mathrm{Fe}^{3+}$ (oct.)が増加する。

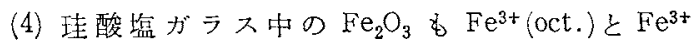
(tetr.) が塩基度や $\mathrm{Fe}_{2} \mathrm{O}_{3} /\left(\mathrm{CaO}, \mathrm{Na}_{2} \mathrm{O}\right)$ の比によって左右 される㑯向を示し， $\mathrm{Fe}^{3+}$ (oct.) は network modifier とし て作用し，珪酸陰イオンを切断すると考えられる。

(5) $\mathrm{CaO}-\mathrm{SiO}_{2}$ 系比比べて $\mathrm{Na}_{2} \mathrm{O}-\mathrm{SiO}_{2}$ 系では塩基性であ るため, $\mathrm{Fe}^{3+}$ (tetr.)が多く存在し，理酸除イオンに大き な作用を示さないが， $\mathrm{Fe}_{2} \mathrm{O}_{3}$ の増加に伴って $\mathrm{Fe}^{3+}$ (oct.)の 割合が多くなり，珪酸陰イオンに network modifier とし て作用すると推定された。

\section{文献}

（1）森永健次，杉之原幸夫，柳个瀬 勉：金属学会誌， 40(1976)，480.

（2）杉之原幸夫，柳ヶ賴 勉：金属学会誌，31(1967)， 1229 .

（3）杉之原幸夫，柳ケ瀬 勉：金属学会誌，33(1969)， 442 .

（4）森永健次，付藤恒男，杉之原幸夫，柳厅瀬 勉：金 掘学会誌，38(1974)，1065.

（5）中村 䕀，杉之原幸夫，柳瀬 勉：金属学会誌， $39(1975), 48$.

(6) R.Roy and P.T.Sarjeant : J.Amer.Ceram.Soc., $52(1969), 57$.

(7) R.A.Schroeder and L.L.Lyons: J.Inorg. Nucl. Chem., 28(1966) , 1155.

(8) P.Kanter and A. Revcolevschi, et al. : J.Mater. Science., 8(1973), 1359.

(9) R.Roy and P.T.Sarjeant : J.Amer.Ceram.Soc., 50(1967), 500 .

(10) P.Tarte: Physics of non Crystalline Solides, North. Holland Pub.Co.(Amsterdam), (1965), 549.

(11) J.Bock and C-J.Su : J.Amer.Ceram.Soc., 53 (1970), 69.

(12) B.D.Saksena : Trans.Farad.Soc., 57 (1961), Part $2,242$.

（13）杉之原幸夫，柳厅瀨 勉，伊藤 尚：溶融笽，12 (1969), 151.

(14) A.Dietzel : Z.Electrochemie, 48(1942), 8 .

(15) H.J.Whitefield : Austral.J.Chem.,20(1967), 859.

(16) E.F. Riebling : J.Amer.Ceran.Soc.,51 (1968), 43.

(17) G.H.Frischat and G.Tomandl : Glastechn.Ber., 42(1969), 182.

(18) F.Danchill and R.Roy : Z. Krist., 111(1959), 462. 